The First James Russell Goding

Memorial Lecture

of the

Australian Society for Reproductive Biology

\title{
THE OVINE AND BOVINE OESTROUS CYCLE
}

\author{
AN APPRECIATION OF J. R. GODING'S CONTRIBUTION TO THE \\ UNDERSTANDING OF THE OESTROUS CYCLE* \\ I. A. GUMMING \\ Department of Agriculture, Victoria, S.S. Cameron Laboratory, \\ State Research Farm, Werribee, Victoria 3030, Australia
}

(Received 1st October 1974)

Today I honour the memory of James Russell Goding, my past colleague and mentor. I worked closely with Jim Goding throughout a period in his life when he contributed much to our understanding of reproductive physiology. I first met him in the mid 1960s when he and Dr W. Hansel visited the State Research Farm, Werribee. From that day, our friendship quickly developed and continued to grow as we undertook joint research programmes. To us both, it felt as if we were moving from one exciting discovery to the next-as if we were continually 'riding high'. The excitement of measuring LH in ovine plasma, of identifying peaks of $\mathrm{LH}$ occurring about the time of oestrus, of identifying the luteolytic properties of prostaglandin (PG) $\mathrm{F}_{2 \alpha}$ and of actually measuring FSH in ovine plasma were just four of these exciting developments. I know of the intense satisfaction of Jim Goding at having established his own viable research group within the Department of Physiology, University of Melbourne, and of the close collaboration he developed with other research groups both within Australia and overseas. Two groups with which he developed particularly close contacts were the Reproductive Section of the Department of Agriculture, Victoria, and the Medical Research Centre, Prince Henry's Hospital, Melbourne. It is about this collaborative research programme and of Jim Goding's influence on it that I wish to speak today.

I suggest that in the field of reproductive physiology, it is the insight he gave us into the oestrous cycle for which he will be long remembered. To enable an understanding of his particular contributions to the study of the oestrous cycle we could well briefly reflect on Jim Goding's distinguished career.

JAMES RUSSELL GODING'S CAREER

After graduating with honours in medicine from Melbourne University, Jim Goding soon became Senior Resident Medical Officer at Prince Henry's

\footnotetext{
* Delivered at the Medical Centre, University of Melbourne, August 1974.
} 
Hospital, Melbourne. In 1940, in the year of his marriage, he enlisted in the A.I.F. and, after spending a time in the Middle East and Java, was taken prisoner of war. Three years later, he was released from prison camp. In 1947, Jim Goding was appointed Medical Superintendent of Prince Henry's Hospital and shortly afterwards entered private practice. From this period, he became more and more absorbed in the research programmes of the Department of Physiology, becoming a Junior Research Fellow supported by the Wool Industry Research Fund. He remembered part of these earlier days in the last 100 words he ever dictated for possible future publication: ". . . credit should go to my personal colleague Derrick Denton who first asked the question, 'Why couldn't we put an endocrine gland in the neck to gain access to its blood supply?" " Jim Goding continued, "Professor R. D. Wright was largely responsible for the enunciation of the rigorous physiological principles of endocrinological investigation which were the bases for the reproduction research programme undertaken at Werribee." In Jim's own special way, he added the aside that Professor Wright "didn't necessarily always follow his own precepts" and referred us to a paper on decerebration.

The Australian Wool Industry continued to support Jim throughout the remainder of his life, both as a Senior Wool Industry Research Fellow (1958-68) while working at the Howard Florey Laboratories of Experimental Physiology, Department of Physiology, University of Melbourne, and as the Senior Research Fellow-in-Charge, Reproduction Research Section, Department of Physiology, University of Melbourne.

We today are aware of his considerable contributions to the understanding of adrenal function and electrolyte balance. Many of the techniques, concepts and approaches developed during this period were extremely valuable to Jim Goding and those who worked with him during the later years of his life. In this latter period, his research was almost entirely devoted to the enunciation of endocrine events controlling ovulation, maintenance of the corpus luteum function, luteolysis, pregnancy and parturition.

I must add one further note to this brief synopsis. Jim Goding was keenly interested in amateur radio and electronics and this interest was a source of enormous satisfaction and interest to him. This interest in circuits and feedbacks was regularly demonstrated in his searching for overall control systems regulating either the oestrous cycle or some other physiological event.

\section{THE PHYSIOLOGIGAL APPROAGH}

Jim Goding attempted to use rigorous physiological approaches in the study of the reproductive cycle. As he practised it, this was to (1) determine secretion rates and concentration in peripheral plasma of the hormones involved in reproduction defined in terms of their magnitude and time of secretion; (2) determine whether the timing and magnitude of secretion of one or more of these hormones was able to account for the observed phenomena under study; (3) appraise the evidence defining the mechanism of secretion of the hormones involved in reproduction, and (4) set up experimental models of test situations which would examine the validity of hypotheses concerning the causal relationships between hormones. 
Many, but not all, of the endocrinological events controlling the oestrous cycle are interrelated by a series of positive feedbacks, each with a time delay occurring between the secretion of a 'controlling' hormone and the response in its respective specific receptor system. At the foundation meeting of the Australian Society for Reproductive Biology, Jim Goding first advanced this concept. To him, it was a chicken or egg dilemma for, at what ever point he started to describe the events of the oestrous cycle, he was left, inevitably, in the situation of having to describe the consequences of the events immediately preceding that step.

I am certainly faced with this dilemma today. Rather than cope with it, I acknowledge it, and will trace historically a number of valuable contributions Jim made to our understanding of the oestrous cycle.

THE OVARIAN, UTERINE AND UTERO-OVARIAN AUTOTRANSPLANTS

Goding, McCracken \& Baird (1967) first reported the transplantation of an ovary and its vascular pedicle to a subcutaneous site in the neck with vascular anastomoses to a carotid artery and jugular vein. This work was carried out during 1965-66, a period in which Jim worked at the Worcester Foundation with the primary aim of testing the feasibility of making ovarian transplants with a procedure modified from the adrenal transplant preparation. This was a period in which Dr Pincus remarked that Jim Goding had half his Foundation working for him. In Jim Goding's report of his 1965-66 overseas tour, he noted that "... in some ways the pièce de résistance was making an ovarian transplant in a heifer at Cornell University. This procedure carried out under rather adverse conditions, took eight hours and more, and nearly killed me. It was, however, very successful".

The procedures of transplanting an ovary, uterus or ovary and uterine horn have been described previously in a number of publications. In recent years, however, J. R. Goding, R. Baxter, W. A. Chamley and I. A. Cumming (unpublished observations) adapted the utero-ovarian autotransplant so that either the uterus or the ovary could be infused. This development and the technique of continuous intra-arterial infusion of the autotransplanted ovary and collection of utero-ovarian venous blood is shown in Text-fig. 1 .

These techniques of autotransplantation have had a wide variety of applications in the study of the oestrous cycle, particularly in studies of steroid biosynthesis and control of luteal function. The technique of autotransplantation avoided the difficulties of obtaining serial samples from individual animals by means of indwelling cannulae in ovarian veins or of pooling single measurements from different animals in a group. The technique allowed the direct measurement of hormones otherwise diluted in the peripheral blood and requiring alternative techniques of indirect measurement. The major advantage was that of long-term accessibility to both the arterial and venous systems of the ovary of conscious and unstressed animals.

This technique of autotransplantation confirmed the dependence of normal luteal regression and ovarian cyclicity to the contiguous relationship of ovary 
and uterus. Transfer of either uterus or ovary alone resulted in extension of the lifespan of corpora lutea but when the ipsilateral ovary and uterine horn were transferred without separating the arterial venous plexus, the CL lifespan was 15 to 16 days as in a ewe experiencing regular oestrous cycles. It was not until Jim Goding and his colleagues separated the ovarian artery from the uteroovarian vein that the importance of maintaining the close apposition of vessels in this plexus was realized.

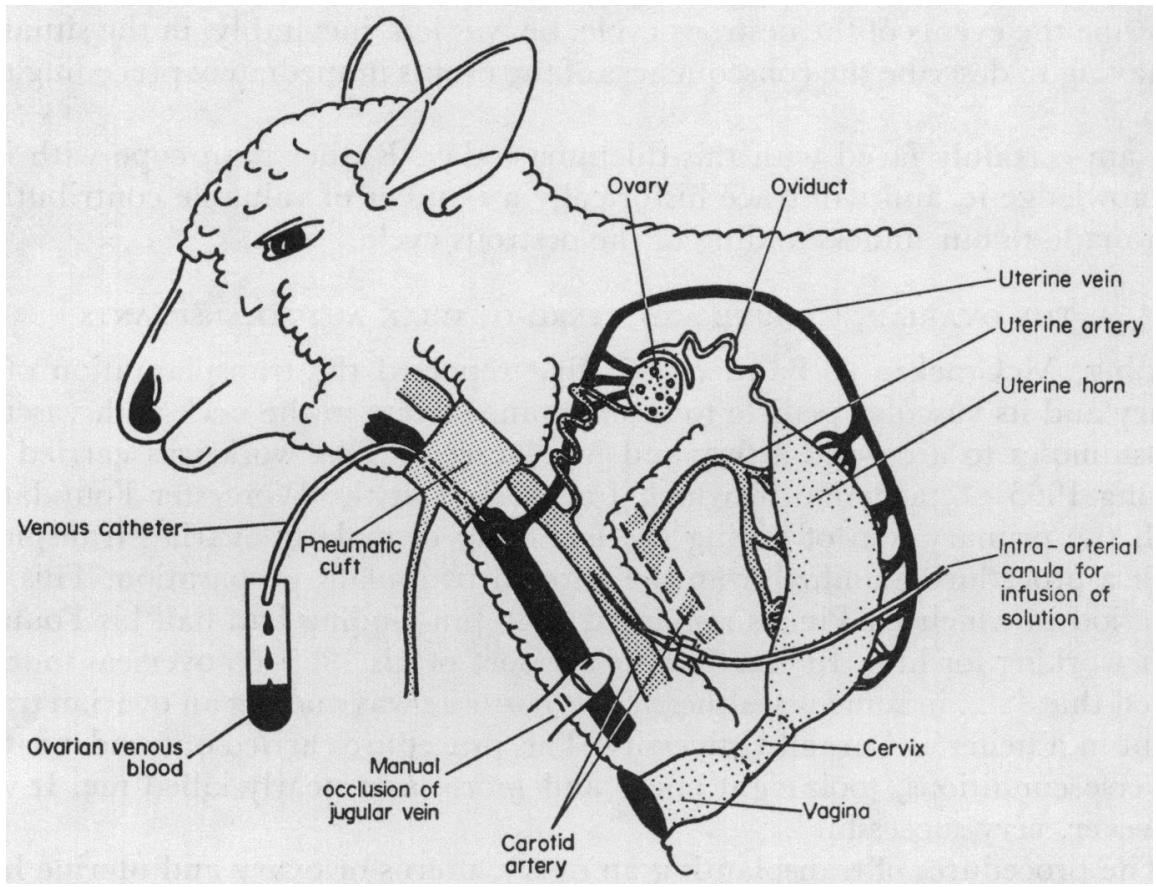

TEXT-FIG. 1. Diagram of utero-ovarian transplant in the ewe, showing anastomosis of the utero-ovarian vein and ovarian artery with vessels in a preformed jugulo-carotid loop and anastomosis of the uterine artery with the contralateral carotid artery. The technique for the continuous intra-arterial infusion of the autotransplanted ovary and the periodic collection of utero-ovarian venous blood is also shown.

I cannot leave this section of my lecture without reference to Müllerian duct mutilation. Jim Goding drew my attention to the following colourful passage from the scientific literature: "This concept (of a luteolysin) has inflamed the imagination of many and resulted in a convergence of effort on this problem which, to this day, has not produced any well-documented evidence for the existence of such a luteolytic substance. Evidence for the existence of luteolytic mechanisms has been adduced from the most imaginative mutilations of the Müllerian duct system which have involved amputation of halves, thirds or fifths of the uterine horns or of the whole uterus, its slashing, its transplantation in whole or in part, and its deflection away from the ovaries as well as combinations of such surgical incursions. In fact, it is doubtful if any imaginable surgical insult to the system remains unperformed as of this writing". Of course, Jim Goding was among the first to acknowledge that Nalbandov \& Cook (1968) 
were justified in taking this attitude to indiscriminate surgical procedures. But we now remember Jim Goding as a surgeon who through his leadership in innovative surgery gave us a series of preparations which have been used to the greater understanding of ovarian and uterine function.

\section{PREOVULATORY SURGE OF LH}

In 1969, I had the pleasure of being one of the joint authors of a paper entitled "Radioimmunoassay for ovine luteinizing hormone. Secretion of luteinizing hormone during estrus and following estrogen administration in the sheep" (Goding, Catt, Brown, Kaltenbach, Cumming \& Mole, 1969). This was my first major publication in the field of reproductive endocrinology and the stimulus I received from Jim during the period that led up to this publication has remained with me. No longer was it necessary to study ovine gonadotrophins by indirect observation and bioassay techniques. This paper described an assay developed from a procedure previously used to assay human growth hormone, luteinizing hormone, placental lactogen and angiotensin. The assay was quick and easy to perform, cheap and had acceptable accuracy, precision and specificity. In fact, for a period it became almost our 'bread and butter'. I wish to recall the major findings reported in this, Jim Goding's first major paper on ovine LH. The paper describes how daily plasma samples were taken from ewes and then reported that in twenty of these animals, a high value of up to $50 \mathrm{ng}$ $\mathrm{LH} / \mathrm{ml}$ was observed at oestrus in one bleed only. Applying the physiological approach outlined before, Jim initiated studies to determine the magnitude and time of secretion of the oestrous surge of LH. I can well remember these early bleeding trials-with no indoor penning, no surgery, an office-cum-laboratory a $100 \mathrm{yd}$ away and lighting at night by a single-torch-light. Whatever the physical limitations, a number of detailed studies were completed. The paper gave an account of a number of oestrous LH releases (Text-fig. 2a) and described how administration of oestradiol-17 $\left(\mathrm{E}_{2}\right)$ to anoestrous ewes either as an injection (Text-fig. $2 \mathrm{~b}$ ) or infusion (Text-fig. 2c) resulted in an LH release typical of that seen at oestrus.

Following the initial publication of Goding et al. (1969), studies of the preovulatory surge of LH continued, using four major classes of ewe each with their particular advantages and characteristics.

(1) The ovarian autotransplant. These ewes have persistent corpora lutea, luteolysis can be induced reliably by ovarian infusion with $\mathrm{PGF}_{2 \alpha}$ and there is ease of collection of ovarian effluent.

(2) The entire ewe during the anoestrous season. These ewes have relatively inactive ovaries, the primary follicles are responsive to PMSG and there are usually no corpora lutea and hence no major source of progesterone.

(3) The entire ewe during the oestrous season. At Werribee, we regularly had daily observations of up to 300 entire ewes and the majority of ewes experienced regular oestrous cycles, thus enabling selection of animals at any stage of the oestrous cycle.

(4) The ovariectomized or spayed ewe. These ewes have elevated LH and FSH levels and provided useful models for feedback studies.

Using spayed ewes, we determined that withdrawal of progesterone was 
followed by no release of LH. In entire or spayed ewes, the presence of progesterone ensured that no $\mathrm{LH}$ release followed exogenous treatment with $\mathrm{E}_{2}$ or the elevation of endogenous levels of $E_{2}$. The presence of $E_{2}$ with no progesterone, however, caused a release of LH. Infusions of $\mathrm{E}_{2}$ confirmed that it was the presence of $\mathrm{E}_{2}$ and not the falling levels of that steroid which caused the preovulatory peak. The quantities of exogenous $\mathrm{E}_{2}$ required to cause an LH surge and the time intervals involved were comparable to the endogenous $E_{2}$ secreted before the preovulatory LH surge as determined from the ovarian autotransplant. This confirmed that the timing and magnitude of the secretion of $E_{2}$ was able to account for the observed LH surge. Similarly, the endogenous

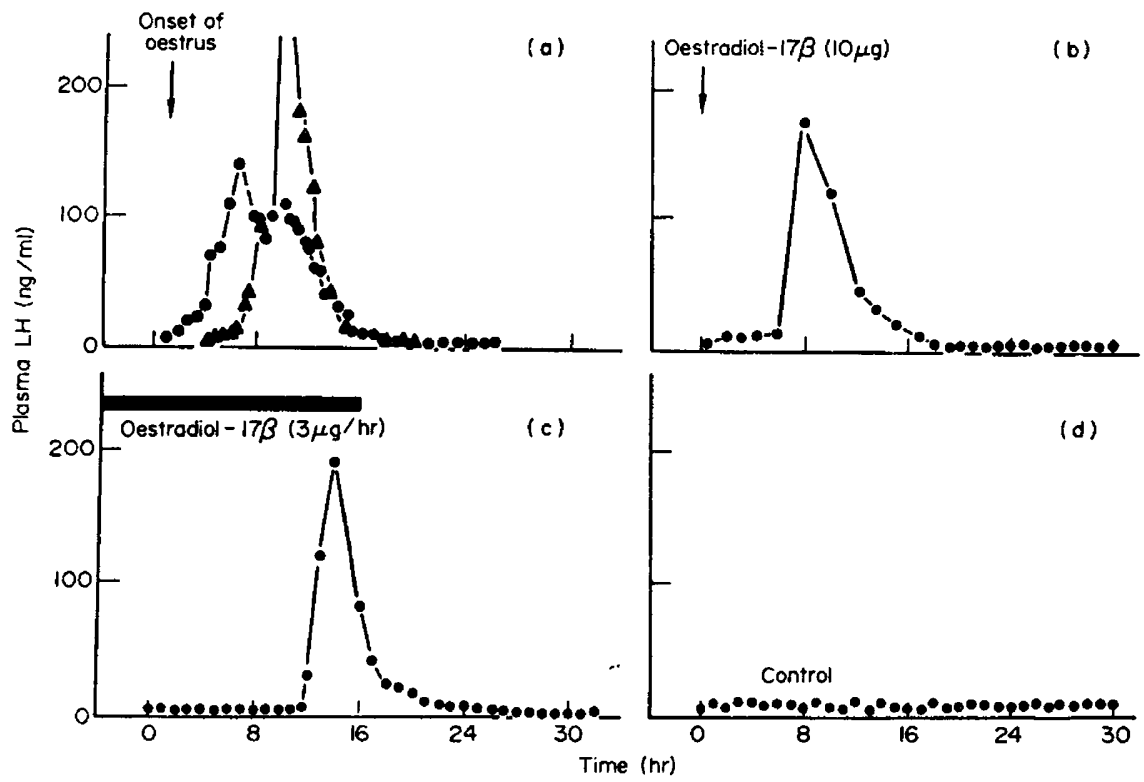

TEXT-FIG. 2. (a) Plasma LH concentration during oestrus in two ewes; (b) effect of an intramuscular injection of oestradiol-17 $\beta$ on the plasma LH concentration of an anoestrous ewe; (c) effect of an intravenous infusion of oestradiol-17 $\beta$ on the plasma LH concentration of an anoestrous ewe; (d) plasma LH levels in an untreated anoestrous ewe. (Reproduced by permission from Goding et al., 1969.)

circulating levels of progesterone throughout the mid- and late luteal phase of the oestrous cycle was able to account for the observed absence of $\mathrm{LH}$ peaks during those parts of the oestrous cycle even though endogenous $\mathrm{E}_{2}$ levels were known to rise during those phases to levels comparable to those seen in the follicular phase. Thus, luteolysis with its fall in plasma progesterone level was shown to permit the later wave of follicular development and its associated rise in $\mathrm{E}_{2}$ secretion and to initiate the preovulatory surge of $\mathrm{LH}$.

\section{ATTEMPTS TO INTEGRATE EVENTS DURING THE OESTROUS GYCLE}

The first scheme of endocrine events occurring during the oestrous cycle of the sheep published by Goding and his co-workers (Cumming, Brown, Blockey \& Goding, 1971) was presented at this Society's annual meeting in 1970 
(Text-fig. 3). It was subsequently amended by McCracken, Baird \& Goding (1971) for presentation at the Laurentian Hormone Conference later that year.

The then commonly assumed rôle for FSH fitted fairly neatly into the scheme (Text-fig. 4) as we once envisaged it. Obviously, the necessary direction of our

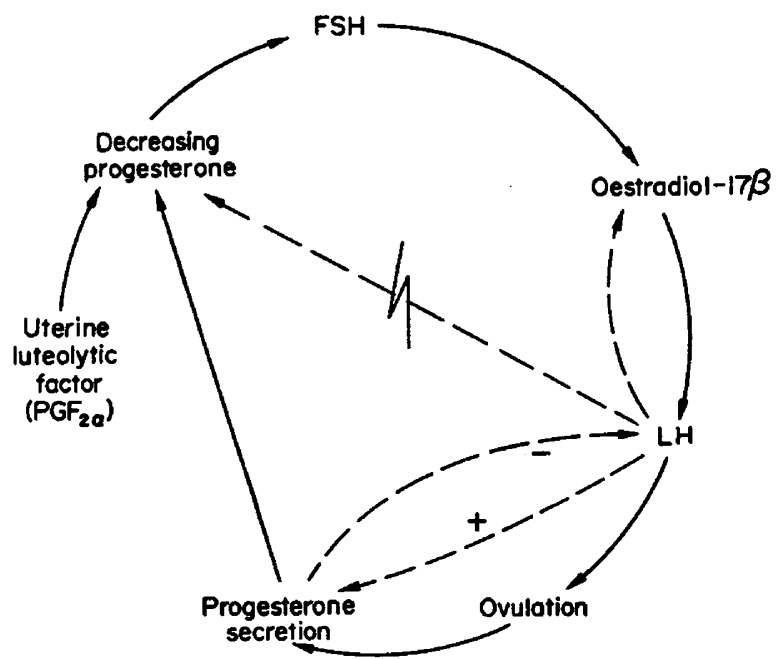

Text-Fig. 3. A model for the control of the ovine oestrous cycle. (Reproduced by permission from Cumming et al., 1971.)

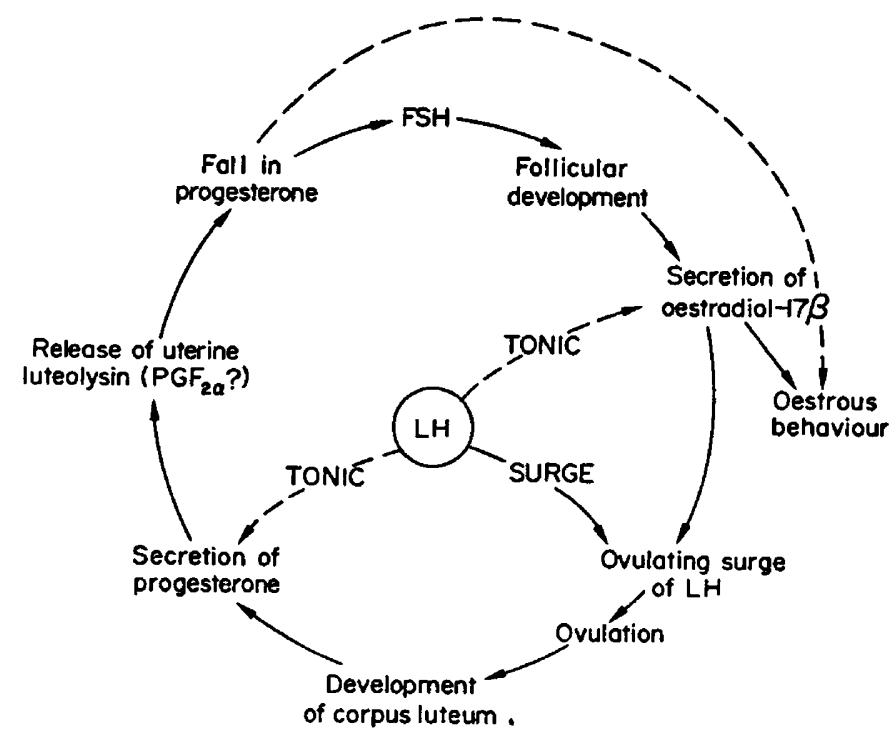

TexT-FIG. 4. Schematic diagram of the probable sequence of endocrine events occurring during the oestrous cycle of the sheep. (Reproduced by permission from McGracken et al., 1971.)

research was to confirm that $\mathrm{PGF}_{2 \alpha}$ was the uterine luteolysin, that FSH was released subsequent to the fall in progesterone and that, in so doing, it stimulated follicular development and the secretion of $E_{2}$. This was followed by the $E_{2}$ induction of the preovulatory surge of $\mathrm{LH}$. 
PROSTAGLANDIN $F_{2} \alpha$, THE UTERINE LUTEOLYSIN IN THE EWE AND COW The evidence for the existence of a uterine luteolysin was listed by Jim Goding in 1973.

1. Excision of the uterus results in prolonged luteal maintenance.

2. Partial excision of the uterus extends the lifespan of the corpus luteum, roughly in proportion to the amount removed. This effect is confined to the corpus luteum adjacent to the portion of uterus removed, i.e. it is a local effect.

3. Transplantation of the ovary, leaving the uterus in situ, also extends the lifespan of the corpus luteum.

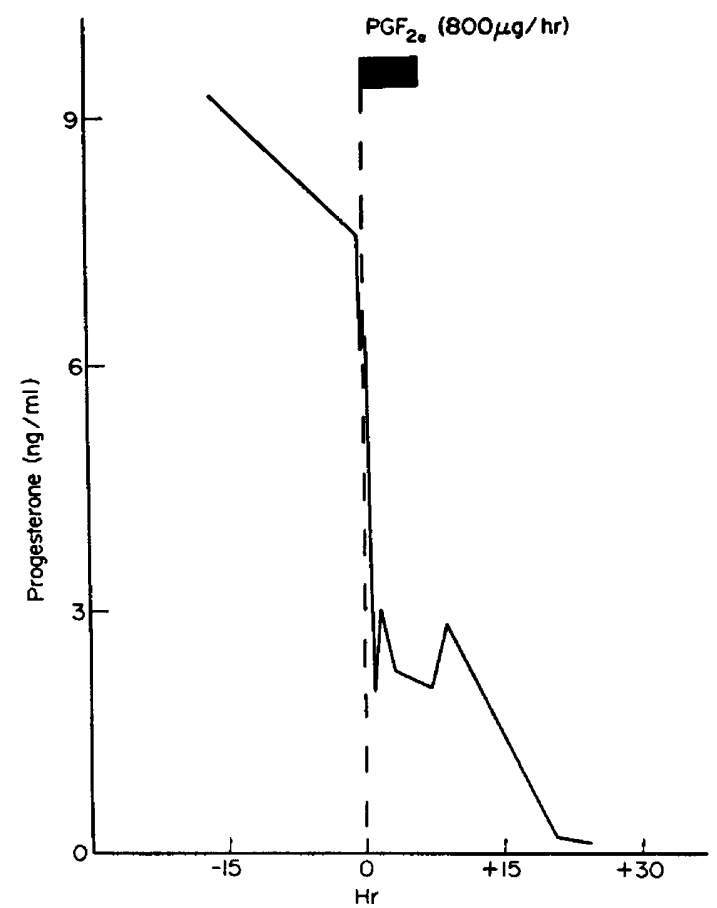

TEXT-rig. 5. The effect of intrauterine infusion of $\mathrm{PGF}_{2 \alpha}$ on the plasma concentration of progesterone in the cow during the mid-luteal phase. (Reproduced by permission from Goding et al., 1971/72.)

4. Transplantation of the uterus, leaving the ovary in situ, also results in luteal maintenance.

5. Transplantation of both ovary and uterus, together, as a single block of tissue, results in normal cyclical function.

6. Infusion and cross-circulation experiments have demonstrated the presence of a luteolysin in utero-ovarian venous blood at the time of luteolysis.

In recent years, the evidence that $\mathrm{PGF}_{2 \alpha}$ is the uterine luteolysin has steadily evolved. Jim Goding and his research team and McCracken's group independently demonstrated that $\mathrm{PGF}_{2 \alpha}$ was a very potent luteolysin in the ewe. 
In 1971, Goding and his co-workers (Goding \& co-authors, 1971/72) demonstrated that $\mathrm{PGF}_{2 \alpha}$ was also a potent luteolysin in cattle by using intrauterine infusion (Text-fig. 5). At that time, Goding et al. concluded that PGs might have important applications to the cattle industry, particularly for extensive beef production, if a suitable means of administration could be found and if fertility subsequent to induced luteolysis proved to be unimpaired.

Studies confirmed that $\mathrm{PGF}_{2 \alpha}$ could be identified in uterine venous blood at the time of luteolysis. This was clearly illustrated for the cow (Text-fig. 6) in the study by Nancarrow \& co-authors (1973).

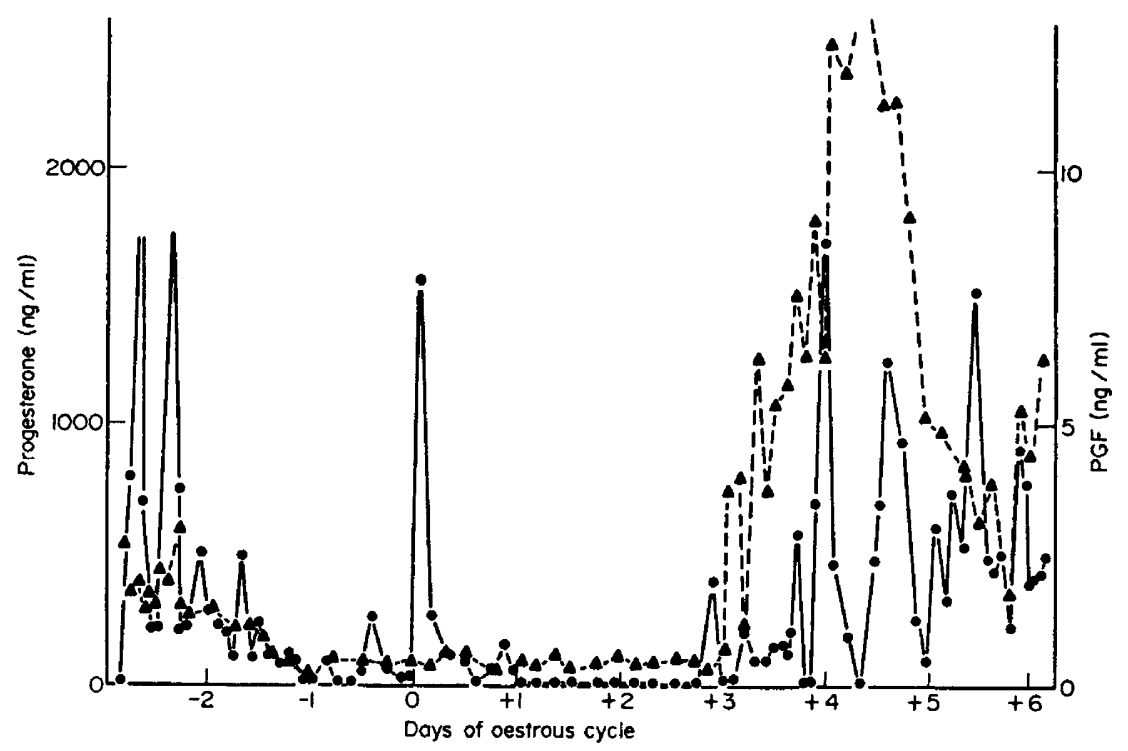

TEXT-FIG. 6. Utero-ovarian plasma progesterone (- . -) and PGF $(-)$ in a cow around oestrus. (Reproduced by permission from Nancarrow et al., 1973.)

A mechanism by which $\mathrm{PGF}_{2 \alpha}$ might gain access to the ovarian supply had to be described. I can vividly remember Jim Goding coming into the laboratory one morning in May 1970 and asking me, "How does the PGF $_{2 \alpha}$ get from the uterus to the ovary?"' Before long, he proposed for the first time that PGF ${ }_{2 \alpha}$ could be transferred locally to the ovarian artery from the utero-ovarian vein by a 'counter-current' mechanism. An experiment separating the ovarian artery from the utero-ovarian vein to test the hypothesis was designed and was later reported by Barrett to this Society in 1970 (Barrett \& co-authors, 1971).

Evidence regarding this 'counter-current' hypothesis has been accumulating, some of which supports the hypothesis and some of which apparently does not. I would suggest that the next few years will see an elucidation of whether this mechanism and/or others are operating, but for the moment we might do well to study how Jim Goding last schematically presented the process of Iuteolysis (Text-fig. 7). 
FOLLICLE-STIMULATING HORMONE

The development of the FSH radioimmunoassay as finally described by Salamonsen and her co-workers in 1973 (Salamonsen \& co-authors, 1973) was the result of much painstaking research during which Jim gave encouragement and advice. We confirmed that coincident surges of $\mathrm{LH}$ and FSH occurred at oestrus and then demonstrated that $\mathbf{E}_{2}$ administered to anoestrous ewes also caused a simultaneous release of $\mathrm{LH}$ and FSH.

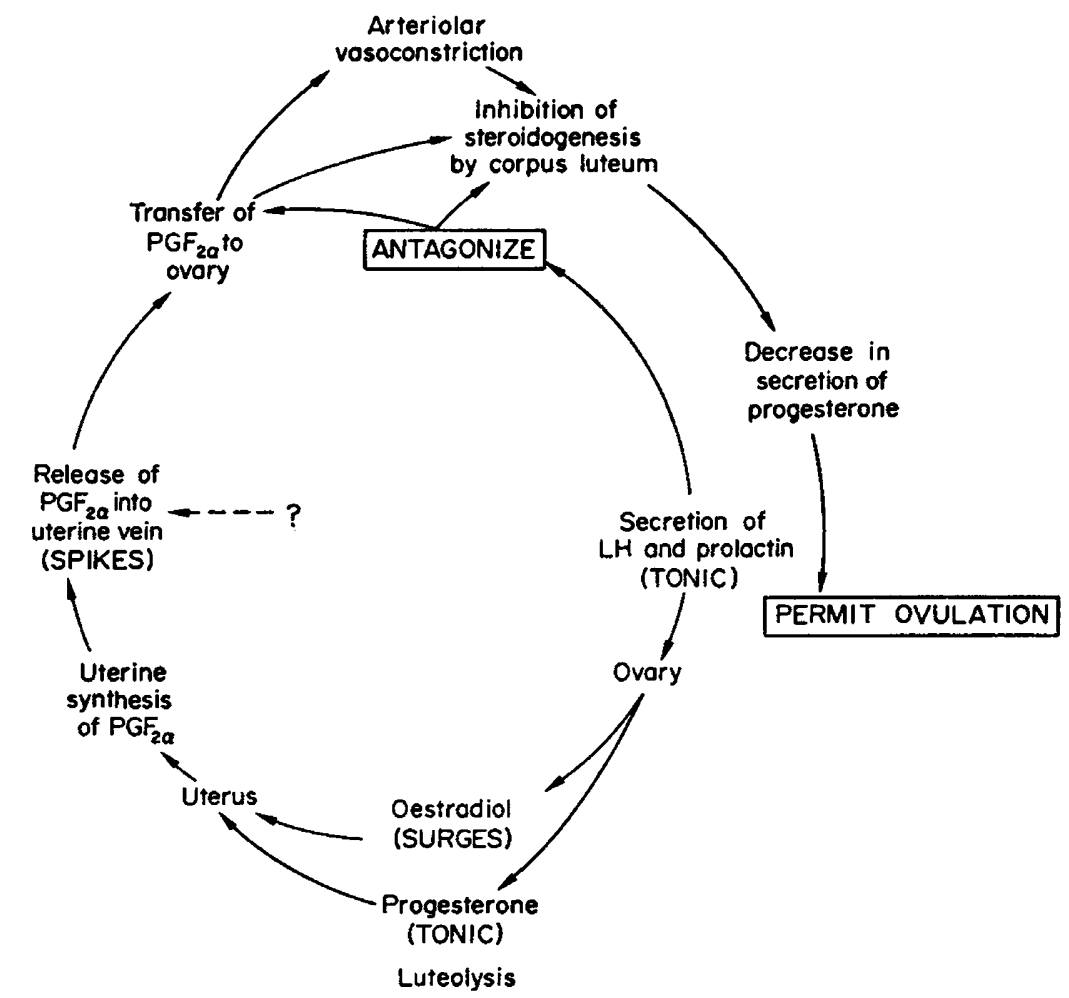

TEXT-FIG. 7. Schematic diagram of the probable sequence of endocrine events occurring during luteolysis in the ewe.

We could, however, find no evidence for the preconceived peak of FSH occurring before oestrus. In fact the reverse applied, with FSH concentrations falling to baseline levels before the simultaneous release of LH and FSH at oestrus. Even this release of FSH was of no greater magnitude than most other releases of FSH found throughout the cycle (Text-fig. 8).

The large changes in plasma FSH which occurred through the oestrous cycle in no way corresponded to the current descriptions of the time course of changes in follicular growth during the luteal phase. In addition, there were no corresponding changes in $\mathrm{LH}$ levels accompanying the large changes in plasma $\mathrm{FSH}$, except about oestrus. 


\section{GONADOTROPHIN-RELEASING HORMONE}

Gonadotrophin-releasing hormone $(\mathrm{Gn}-\mathrm{RH})$ was shown to release $\mathrm{LH}$ and FSH abruptly and coincidently. It appeared probable that during the late follicular phase, high circulating levels of $\mathrm{E}_{2}$ released $\mathrm{Gn}-\mathrm{RH}$ from the hypothalamus. As the gonadotrophin-releasing properties of $\mathrm{Gn}-\mathrm{RH}$ were only in part modulated by progesterone, and were not totally inhibited, it appeared that throughout the remainder of the oestrous cycle progesterone exerted an

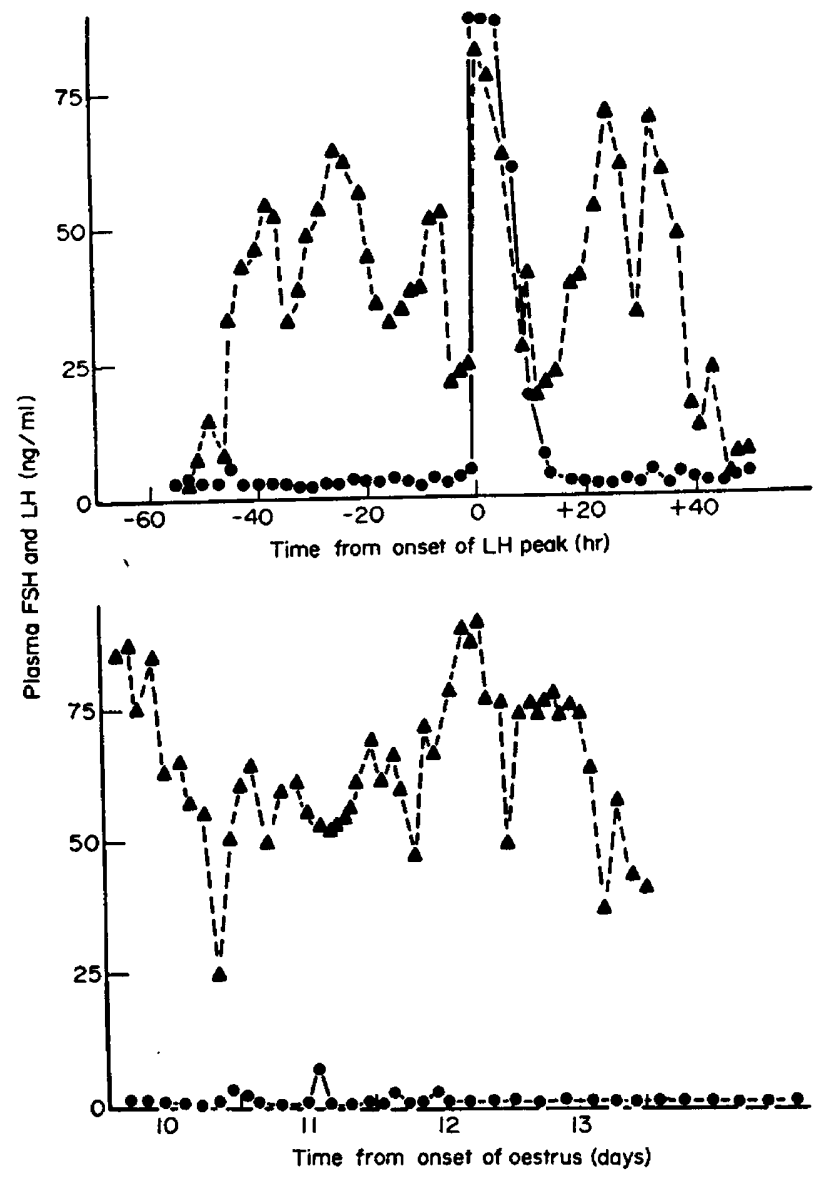

TexT-pIG. 8. Plasma concentrations of FSH (- - ) and LH (-) in two ewes around oestrus and at Days 10 to 13 of the oestrous cycle. (Reproduced by permission from Salamonsen et al., 1973.)

inhibitory action on the $\mathrm{E}_{2}$-evoked surge of $\mathrm{LH}$ at the hypothalamic level rather than at the pituitary.

The search for mechanisms controlling gonadotrophin secretion will continue. As yet, the known properties of Gn-RH cannot explain the differential FSH-LH releases which occur throughout the remainder of the oestrous cycle.

As I recollect, following discussions Jim Goding and I had after our early experiments with Gn-RH and after having measured FSH throughout the 
oestrous cycle, we were beginning to accept the likelihood that a separate follicular cycle was operating within the ovary, and that it was this cyclical activity which had an important part to play in determining the exact oestrous cycle length. This was considered particularly important in the determination of the interval between luteolysis and ovulation (Text-fig. 9).

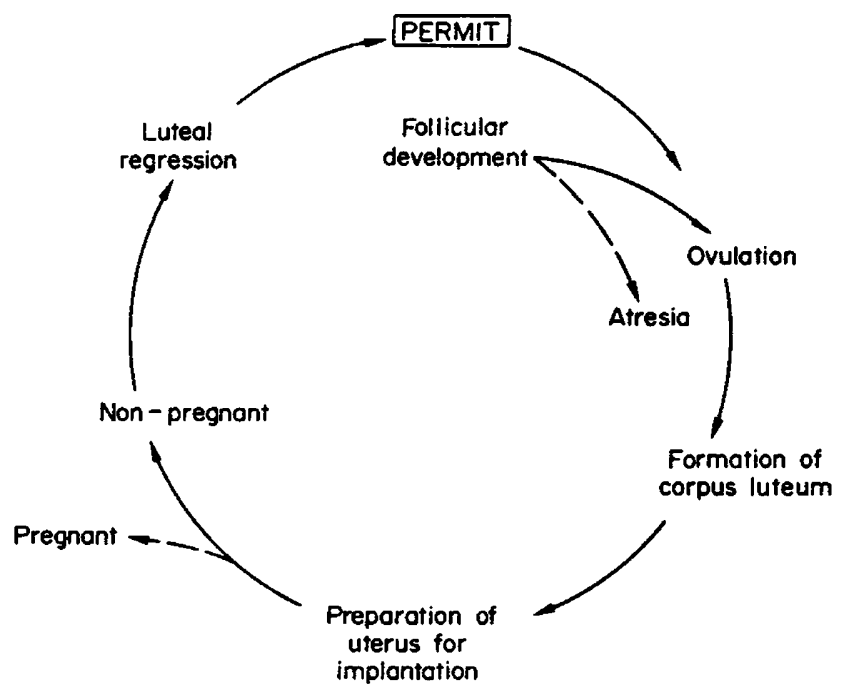

TEXT-FIG. 9. Schematic representation of the events occurring during the ovine oestrous cycle.

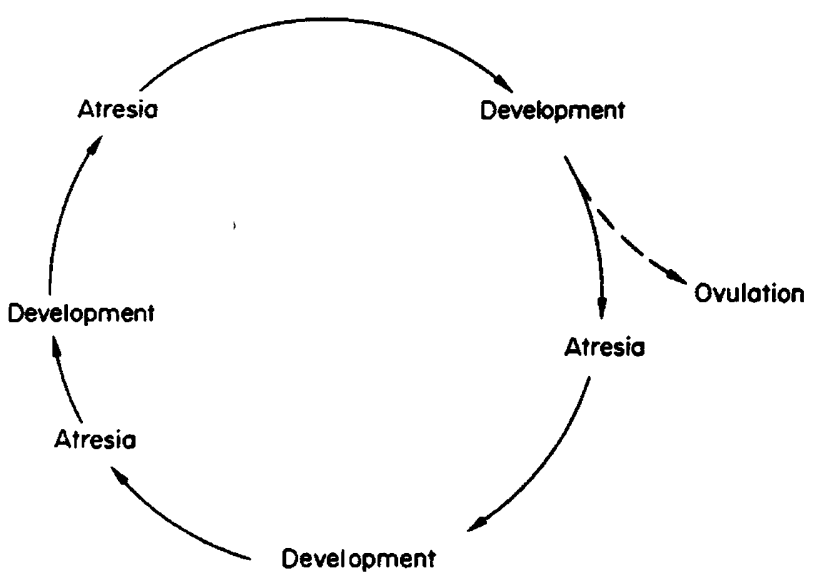

TexT-FIG. 10. Schematic representation of follicular cycles occurring during the ovine oestrous cycle.

Jim pictured a follicular cycle-possibly only interrupted by anoestrus, but of this we never spoke. This follicular cycle was demonstrated diagrammatically (Text-fig. 10). Evidence to support such an hypothesis was beginning to accumulate from both histological and anatomical studies of $E_{2}$ secretion. These latter studies identified waves of $\mathrm{E}_{2}$ secretion occurring from Day 2 to 4 of the 


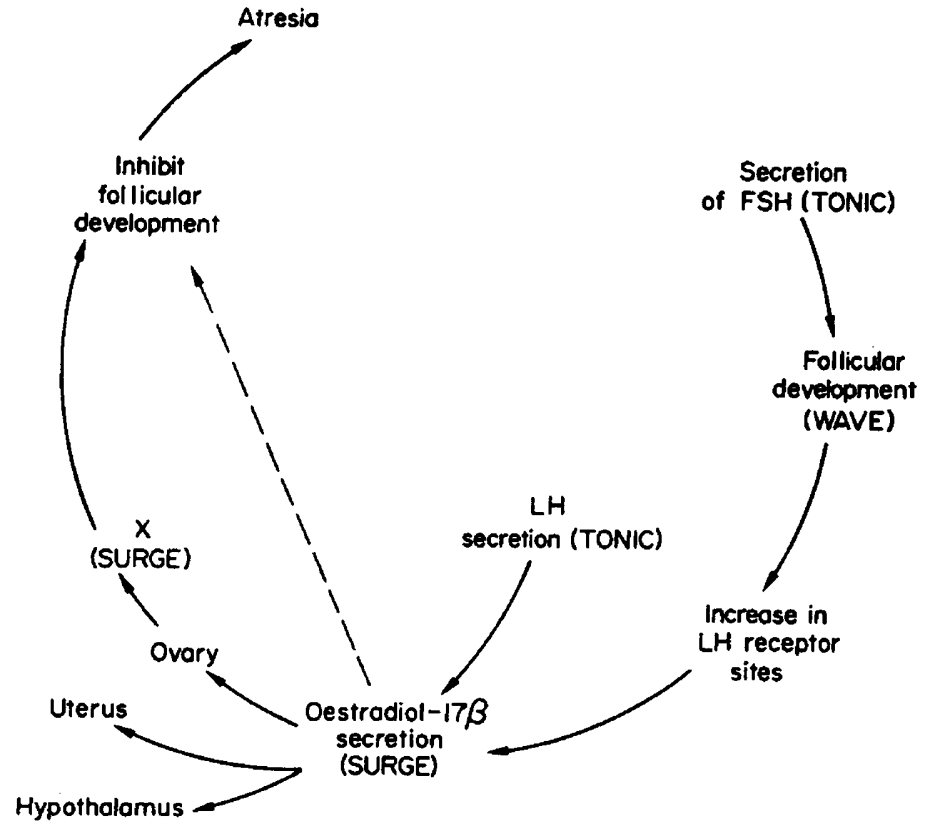

TexT-rig. 11. Schematic representation of the possible control of follicular events during the luteal phase of the ovine oestrous cycle.

cycle and at 4- to 6-day intervals during the luteal phase. Finally, using his typically schematic approach, Jim Goding sketched plans for the possible control of follicular events during the luteal phase (Text-fig. 11) and about the time of oestrus (Text-fig. 12).
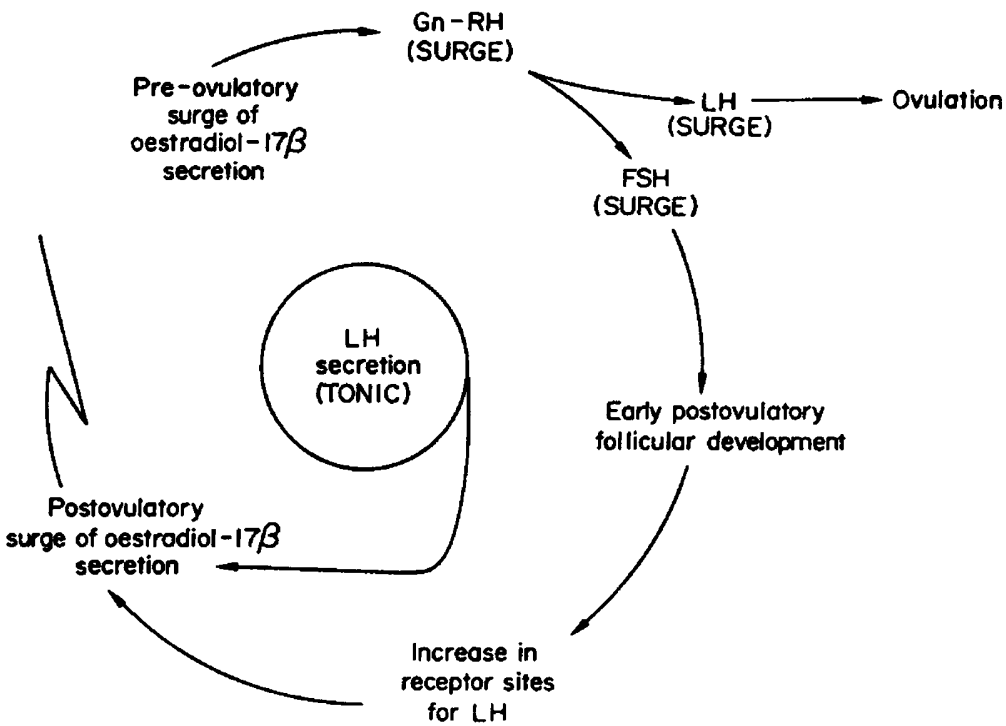

(SURGE)

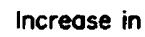

receptor sites

for LH

TExT-FIG. 12. Schematic representation of the possible control of follicular events about the time of oestrus in the ewe. 
FOLLIGULAR DEVELOPMENT

I wish to complete this memorial address by referring briefly to follicular development. Jim Goding's contribution to the understanding of the endocrine events of the oestrous cycle essentially brings us to the point where we can study, meaningfully, such questions as:

Why does any one follicle, rather than any other develop and possibly ovulate?

Why do heavy ewes tend to have a higher proportion of multiple ovulations than lighter ewes?

How do age and genotype of ewe and time in the breeding season affect the endocrine events controlling ovulation?

How can we reliably control twin ovulation in cattle?

\section{CONCLUDING REMARKS}

Jim Goding contributed many valued thoughts and findings to the scientific literature. The immense size and worth of his contribution is so much the more remarkable when we recall that it was not until 1965 that he commenced research in the field of reproductive physiology and it was all too soon that he made his final personal contribution.

I shall forever respect and cherish my memories of James Russell Goding.

\section{REFERENGES}

Barrett, S., Blockey, M. A. de B., Brown, J. M., Cumming, I. A., Goding, J. R., Mole, B. J. \& OвST, J. M. (1971) Initiation of the oestrous cycle in the ewe by infusions of $P_{2 G F_{2 a}}$ to the autotransplanted ovary. F. Reprod. Fert. 24, 136-137.

Gumming, I. A., Brown, J. H., Brockey, M. A. De B. \& Goding, J. R. (1971) Regulation of the oestrous cycle in the ewe. F. Reprod. Fert. 24, 148-149.

Goding, J. R. (1973) The demonstration that PGF $_{2 \alpha}$ is the uterine luteolysin in the ewe. In Le Corps Faune, pp. 311-323. Eds. R. Denamur and A. Netter. Masson, Paris.

Goding, J. R., Gatt, K. J., Brown, J. M., Kaltenbach, G. G., Gumming, I. A. \& Mole, B. J. (1969) Radioimmunoassay for ovine luteinizing hormone. Secretion of luteinizing hormone during estrus and following estrogen administration in the sheep. Endocrinology, 85, 133-142.

Goding, J. R., Gumming, I. A., Ghamlex, W. A., Brown, J. M., Gain, M. D., Gerini, J. G., Gerini, M. E. D., Findlay, J. K., O'Shea, J. D. \& Pemberton, D. H. (1971/72) Prostaglandin F $2 \alpha$, 'the' luteolysin in the mammal? Gynecol. Invest. 2, 73-97.

Goding, J. R., McGracken, J. A. \& Baird, D. T. (1967) A study of ovarian function in the ewe by means of a vascular autotransplantation technique. F. Endocr. 39, 37-52.

MaGracken, J. A., Bajrd, D. T. \& Goding, J. R. (1971) Factors affecting the secretion of steroids from the transplanted ovary in the sheep. Recent Progr. Horm. Res. 27, 537-582.

Nalbandov, A. V. \& Cook, B. (1968) Reproduction. A. Rev. Physiol. 30, 245-278.

Nancarrow, G. D., Buckmaster, J., Ghamley, W., Cox, R. I., Cumming, I. A., Gummins, L., Drinan, J. P., Findlay, J. K., Goding, J. R., Restall, B. J., Schneider, W. \& Thorburn, G. D. (1973) Hormonal changes around oestrus in the cow. F. Reprod. Fert. 32, 320-321.

Salamonsen, L. A., Jonas, H. A., Burger, H. G., Buckmaster, J. M., Ghamley, W. A., Gumming, I. A., FindLAY, J. K. \& Goding, J. R. (1973) A heterologous radioimmunoassay for follicle-stimulating hormone. Application to measurement of FSH in the ovine estrous cycle and in several other species including man. Endocrinology, 93, 610-618. 